Western North American Naturalist 68(1), (C) 2008, pp. 123-127

\title{
STATUS OF THE NORTHERN ROCK DEERMOUSE, PEROMYSCUS NASUTUS (RODENTIA: CRICETIDAE), IN UTAH
}

\author{
George V. Oliver ${ }^{1}$
}

\begin{abstract}
Peromyscus nasutus has been considered to occur in Utah since it was first reported in the state in 1935. Authors since then have considered the distribution of $P$. nasutus to include southeastern Utah. However, the original Utah specimen was later reidentified as Peromyscus boylii. A query of museums revealed only 1 other specimen considered to be P. nasutus from Utah. This specimen was examined and found to be P. boylii. Thus, there is no evidence of the occurrence of $P$. nasutus in Utah, and the northwesternmost accepted records of this species are in the Chuska Mountains of northeastern Arizona.
\end{abstract}

Key words: Peromyscus nasutus, Peromyscus difficilis, northern rock deermouse, northern rock mouse, rock mouse, Peromyscus boylii, brush deermouse, brush mouse, mammals, Utah.

The northern rock deermouse, Peromyscus nasutus (J.A. Allen, 1891), has long been considered a part of the mammalian fauna of Utah, albeit 1 of the rarest mammals in the state. Because of its perceived rarity in Utah, this species was for many years included in the Utah Division of Wildlife Resources' Utah Sensitive Species List (e.g., Utah Division of Wildlife Resources 1997, 1998), and more recently it has been considered a species of potential conservational concern and is included in the Utah Division of Wildlife Resources' Utah Comprehensive Wildlife Conservation Strategy (Sutter et al. 2005). Mammalogical literature continues to indicate the occurrence of $P$. nasutus in Utah. Evidence for the occurrence of this species in Utah is here reevaluated.

Nomenclature used here follows Musser and Carleton (2005). Baker et al. (2003) have advocated slightly different English common names for species of Peromyscus, and they placed this genus in the family Muridae (as did Musser and Carleton 1993) rather than in Cricetidae. Many authors in recent years have treated $P$. nasutus as a species distinct from the southern rock deermouse, Peromyscus difficilis (J.A. Allen, 1891), but others have considered nasutus to be only a subspecies of $P$. difficilis. Musser and Carleton (2005), while tentatively listing both as species, summarized the taxonomic controversy, which they considered to be unresolved, and commented concerning the 2 nominal species that "the matter of their synonymy deserves reconsideration and decisive resolution."

Peromyscus nasutus was first reported from Utah by Benson (1935) based on field work conducted in the vicinity of Navajo Mountain in 1933. In his account for this species, Benson (1935) wrote: "Two caught in a rocky gully at Rainbow Bridge. This species inhabits rocky situations in the juniper zone and doubtless occurs throughout the lower canyons in this region." Seemingly only 1 of these was saved as a specimen, for in the same account Benson referred to "[t]he single specimen from Rainbow Bridge." At the same locality Benson (1935) also reported the capture of the brush deermouse, Peromyscus boylii (Baird, 1855): “One taken at Rainbow Bridge in a rocky sidecanyon." Rainbow Bridge is $8.3 \mathrm{~km}$ north of the Arizona boundary and $\sim 4.4 \mathrm{~km}$ south-southeast of the Colorado River (now inundated by Lake Powell) in extreme southwestern San Juan County, Utah (Fig. 1). Elevations in the vicinity of Rainbow Bridge are $\sim 1100 \mathrm{~m}$.

Durrant (1952), based on Benson's (1935) report and on his own examination of the Rainbow Bridge specimen, included $P$. nasutus in his monograph on the mammals of Utah as part of the accepted fauna of the state. Durrant (1952) noted that he knew of no other specimens of this species from Utah but speculated that "further collecting may reveal its presence in suitable habitat in all of that part of Utah east of the Colorado and Green rivers."

${ }^{1}$ Utah Natural Heritage Program, Utah Division of Wildlife Resources, 1594 West North Temple, Salt Lake City, UT 84116. E-mail: georgeoliver@utah.gov 


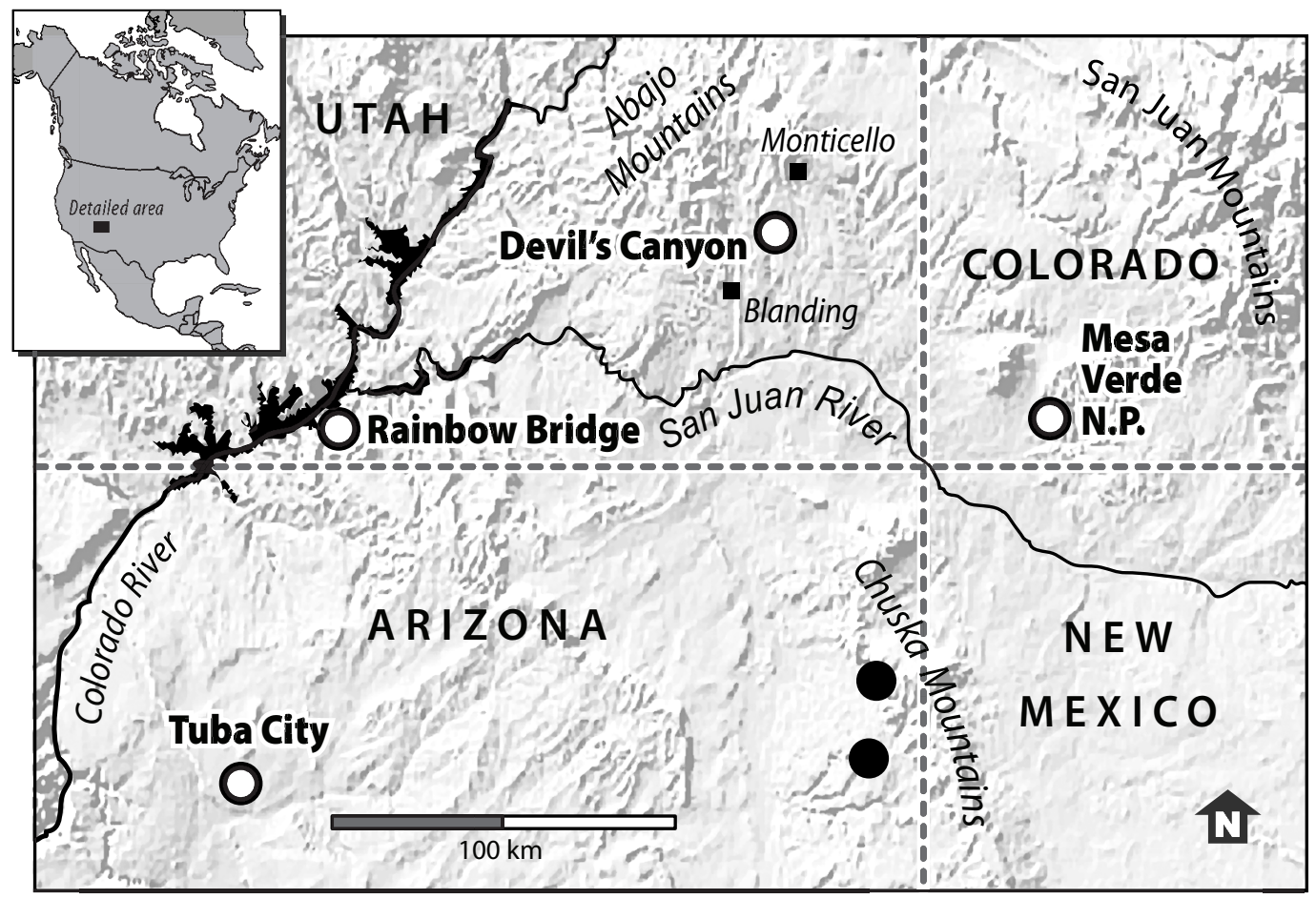

Fig. 1. The Four Corners area (Utah-Colorado-New Mexico-Arizona) showing 4 refuted locational records of Peromyscus nasutus (open circles), 2 undisputed records of this species (solid circles), and various place names mentioned in the text.

Hoffmeister and Diersing reexamined Benson's Rainbow Bridge specimen (no. 61160, Museum of Vertebrate Zoology, University of California, Berkeley) and determined that it was not $P$. nasutus but $P$. boylii (Hoffmeister 1986). They also reexamined a specimen (no. 33403, Museum of Vertebrate Zoology) from Tuba City, Coconino County, Arizona ( 97 km south of the Utah boundary; Fig. 1), considered by Benson (1935), Cockrum (1961), and others (e.g., Hall and Kelson 1959, Hall 1981) to be $P$. nasutus, and concluded that it too was $P$. boylii rather than $P$. nasutus. Hoffmeister (1986) further commented that he did not consider the range of $P$. nasutus to extend into north central Arizona or into Utah. Hoffmeister (1986) did, however, present records of $P$. nasutus from the Chuska Mountains, Apache County, Arizona, the closest of these to Utah being $\sim 63 \mathrm{~km}$ south of the state boundary (Fig. 1), and Findley et al. (1975) had records of this species from just southeast of the Chuska Mountains in McKinley County, New Mexico.

Anderson (1961) reported a single specimen of P. nasutus (no. 69413, University of Kansas
Museum of Natural History, Lawrence) from Mesa Verde National Park, Montezuma County, Colorado, which is the nearest reported locality for this species outside of Utah, $\sim 45 \mathrm{~km}$ east of the state boundary (Fig. 1). However, Armstrong (1972) reexamined Anderson's Mesa Verde specimen and concluded that it is $P$. boylii, adding that he did not consider there to be any valid records of $P$. nasutus west of the San Juan Mountains in Colorado. In fact, the westernmost localities for P. nasutus in Colorado are in the Sangre de Cristo Range (Armstrong 1972, Hall 1981), well to the east of the San Juan Mountains.

A query of museum collections revealed only 1 other specimen considered to be $P$. nasutus that has been collected in Utah. The specimen was collected by Robert S. Hoffmann on 9 June 1973 at Devil's Canyon campground, 10 miles north-northeast of Blanding, San Juan County, which is on the east side of the Abajo Mountains at an elevation of $\sim 2175 \mathrm{~m}$ (Fig. 1). This specimen, in the mammal collection of the University of Kansas Museum of Natural History (no. 154282), is a female, with measurements 
recorded by the collector as follows: total length $213 \mathrm{~mm}$, tail length $112 \mathrm{~mm}$, hind foot length $24 \mathrm{~mm}$, ear length $21 \mathrm{~mm}$, and weight $29.7 \mathrm{~g}$.

The specimen was examined by the author. Tooth wear indicates that it is a moderately old individual. The lower molars $(\mathrm{m} 1, \mathrm{~m} 2)$ are not complex. On both the right and left mandibles, $\mathrm{m} 1$ lacks an entolophulid, and m2 lacks a mesostylid. Left $\mathrm{ml}$ lacks an ectostylid and right $\mathrm{ml}$ possesses an ectostylid. These dental characters suggest $P$. boylii, not $P$. nasutus, according to Hooper (1957), Dalquest and Stangl (1983), and Hoffmeister (1986), but not Cornely et al. (1981), who found no important differences in molar complexity between these 2 species.

Dalquest and Stangl (1983) used characters of the mandibles and lower molars to distinguish 7 species of Peromyscus from transPecos Texas. The anteroconid of $\mathrm{ml}$ of the Devil's Canyon specimen lacks a notch or groove, agreeing with Dalquest and Stangl's (1983) grade 0, which they found in $43 \%$ of $P$. boylii but only in $11 \%$ of P. nasutus that they examined. Alveolar length of the lower molar toothrow (m1-m3) of the Devil's Canyon specimen is $4.14 \mathrm{~mm}$, near the lower end of the range for $P$. nasutus $(4.10-4.70 \mathrm{~mm})$ and near the upper end of the range for $P$. boylii (3.65$4.20 \mathrm{~mm}$ ) (Dalquest and Stangl 1983). The length of $\mathrm{ml}$ is $1.71 \mathrm{~mm}$, which is within the range for $P$. boylii but not for $P$. nasutus (Dalquest and Stangl 1983). Breadth of $\mathrm{ml}$ is $1.00 \mathrm{~mm}$, agreeing with $P$. boylii but not $P$. nasutus (Dalquest and Stangl 1983). As discussed above, the complexity of $\mathrm{ml}$ also agrees more closely with the findings of Dalquest and Stangl (1983) for P. boylii than for P. nasutus.

Cornely et al. (1981) also evaluated characters of 7 species of Peromyscus in trans-Pecos Texas (in the Guadalupe Mountains). Unlike other authors (Hooper 1957, Dalquest and Stangl 1983, Hoffmeister 1986), they did not find any obvious or meaningful differences in the complexity of the upper or lower molars (frequencies of styles and lophs or of stylids and lophids) of $P$. boylii and $P$. nasutus. However, they did find cranial differences between these species. The auditory bullae of the Devil's Canyon specimen are slightly inflated, the condition found in P. boylii, not moderately inflated as in $P$. nasutus (Cornely et al.
1981). The interparietal of the Devil's Canyon specimen is diamond-shaped and pointed anteriorly as in $P$. boylii, not triangular and unpointed anteriorly as in $P$. nasutus (Cornely et al. 1981).

Greatest length of skull of the Devil's Canyon specimen is $27.06 \mathrm{~mm}$, which would be exceptionally small for $P$. nasutus (and is small even for $P$. boylii). Pelage characters of this specimen agree more closely with those of $P$. boylii than with $P$. nasutus. The flanks, and other parts of the dorsum including the head, are suffused with ochre and are not so distinctly or uniformly gray as in typical P. nasutus. Applying the cranial and dental characters discussed above as well as external characters (measurements and pelage), I consider the Devil's Canyon specimen to be $P$. boylii.

In her inventory the mammals of the Abajo Mountains and vicinity, San Juan County, Utah, Schafer (1991) did not detect P. nasutus. Apparently she was unaware of the University of Kansas specimen from Devil's Canyon, and she did not mention $P$. nasutus, not even as a species of hypothetical occurrence. However, she did collect $P$. boylii at a location "9 mi. SSW Monticello" at $7200 \mathrm{ft}(2195 \mathrm{~m})$ elevation, which is approximately the same as that of the University of Kansas specimen, the highway crossing of Devil's Canyon being 9.5 miles south-southwest of the center of Monticello. Durrant (1952), too, examined a specimen of $P$. boylii from Devil's Canyon.

Many technical publications (e.g., Hoffmeister 1951, Hall and Kelson 1959, Hoffmeister and de la Torre 1961, Hooper 1968, Hall 1981, Carleton 1989, Musser and Carleton 1993, 2005, Nowak 1999, Durish et al. 2004) as well as popular works (e.g., Burt and Grossenheider 1980, Planz 1999, Kays and Wilson 2002, Bowers et al. 2004, Reid 2006) have followed Benson (1935) and Durrant (1952) in indicating that the distribution of $P$. nasutus includes southeastern Utah. Furthermore, this species has been considered to be of conservational concern in Utah because of its apparent rarity in this state (Utah Division of Wildlife Resources 1997, 1998, Sutter et al. 2005). Reconsideration of the evidence for the occurrence of this species in Utah, however, does not support its inclusion in the fauna of the state. Because the 1933 Rainbow Bridge specimen and the 1973 Devil's Canyon specimen, which represent the only known evidence of $P$. 
nasutus in Utah, both have been found to be $P$. boylii rather than $P$. nasutus, there remains no reason to consider P. nasutus to occur in Utah. Although P. boylii occurs throughout the Four Corners area of Utah, Colorado, New Mexico, and Arizona (Durrant 1952, Armstrong 1972, Findley et al. 1975, Hoffmeister 1986), the northwesternmost credible records of $P$. nasutus are those in the Chuska Mountains, Apache County, Arizona (Hoffmeister 1986) (Fig. 1).

I thank Michael L. Canning, Kevin D. Bunnell, and Carmen L. Bailey for their encouragement of this work; Robert M. Timm for loan of the specimen in the Museum of Natural History, University of Kansas; Cory L. Maylett for preparation of the figure; and anonymous reviewers for their suggestions. This work was supported by funding from the Nongame Mammals Program of the Utah Division of Wildlife Resources.

\section{Literature Cited}

Anderson, S. 1961. Mammals of Mesa Verde National Park, Colorado. University of Kansas Publications, Museum of Natural History 14:29-67.

Armstrong, D.M. 1972. Distribution of mammals in Colorado. Monograph of the Museum of Natural History, The University of Kansas 3:i-x + 1-415.

Baker, R.J., L.C. Bradley, R.D. Bradley, J.W. Dragoo, M.D. Engstrom, R.S. Hoffmann, C.A. Jones, F. Reid, D.W. Rice, and C. Jones. 2003. Revised checklist of North American mammals north of Mexico, 2003. Occasional Papers, Museum of Texas Tech University 229:1-23.

BENSON, S.B. 1935. A biological reconnaissance of Navajo Mountain, Utah. University of California Publications in Zoology 40:439-455.

Bowers, N., R. Bowers, and K. Kaufman. 2004. Mammals of North America. Houghton Mifflin Company, Boston, MA. 352 pp.

BurT, W.H., AND R.P. GRossenHEIDER. 1980. A field guide to the mammals[,] North America north of Mexico. 3rd edition. Houghton Mifflin Company, Boston, MA. $x x x+289$ pp.

Carleton, M.D. 1989. Systematics and evolution. Pages 7-141 in G.L. Kirkland, Jr., and J.N. Layne, editors, Advances in the study of Peromyscus (Rodentia). Texas Tech University Press, Lubbock. 366 pp.

Cockrum, E.L. "1960" [1961]. The Recent mammals of Arizona: their taxonomy and distribution. University of Arizona Press, Tucson. viii +276 pp.

Cornely, J.E., D.J. Schmidly, H.H. Genoways, and R.J. BAKER. 1981. Mice of the genus Peromyscus in Guadalupe Mountains National Park, Texas. Occasional Papers, The Museum, Texas Tech University 74:1-35.

Dalquest, W.W., and F.B. Stangl, JR. 1983. Identification of seven species of Peromyscus from trans-Pecos
Texas by characters of the lower jaws. Occasional Papers, The Museum, Texas Tech University 90:1-12.

Durish, N.D., K.E. Halcomb, C.W. Kilpatrick, and R.D. Bradley. 2004. Molecular systematics of the Peromyscus truei species group. Journal of Mammalogy 85:1160-1169.

DURRANT, S.D. 1952. Mammals of Utah: taxonomy and distribution. University of Kansas Publications, Museum of Natural History 6:1-549.

Findley, J.S., A.H. Harris, D.E. Wilson, and C. Jones. 1975. Mammals of New Mexico. University of New Mexico Press, Albuquerque. xxii +360 pp.

HaLL, E.R. 1981. The mammals of North America. Volume II. 2nd edition. John Wiley \& Sons, Inc., New York. $\mathrm{vi}+581+90 \mathrm{pp}$.

HaLl, E.R., and K.R. Kelson. 1959. The mammals of North America. Volume II. Ronald Press, New York. $\mathrm{x}+537+79 \mathrm{pp}$.

Hoffmeister, D.F. 1951. A taxonomic and evolutionary study of the piñon mouse, Peromyscus truei. Illinois Biological Monographs 21(4):i-xx + 1-104.

1986. Mammals of Arizona. University of Arizona Press, Tucson. $\mathrm{xx}+602 \mathrm{pp}$.

Hoffmeister, D.F., and L. DE LA Torre. 1961. Geographic variation in the mouse Peromyscus difficilis. Journal of Mammalogy 42:1-13.

Hooper, E.T. 1957. Dental patterns in mice of the genus Peromyscus. Miscellaneous Publications, Museum of Zoology, University of Michigan 99:1-59.

1968. Classification. Pages 27-74 in J.A. King, editor, Biology of Peromyscus (Rodentia). Special Publication No. 2, American Society of Mammalogists. xiii $+593 \mathrm{pp}$.

KaYs, R.W., AND D.E. WiLSON. 2002. Mammals of North America. Princeton University Press, Princeton, NJ. $240 \mathrm{pp}$.

Musser, G.G., and M.D. Carleton. 1993. Family Muridae. Pages 501-755 in D.E. Wilson and D.M. Reeder, editors, Mammal species of the world[:] a taxonomic and geographic reference. 2nd edition. Smithsonian Institution Press, Washington, DC. xviii + 1206 pp. 2005. Superfamily Muroidea. Pages 894-1531 in D.E. Wilson and D.M. Reeder, editors, Mammal species of the world[:] a taxonomic and geographic reference. 3rd edition. Volume 2. Johns Hopkins University Press, Baltimore, MD. xvii + 1399 pp.

NoWAK, R.M. 1999. Walker's mammals of the world. 6th edition. Volume II. Johns Hopkins University Press, Baltimore, MD. xii + 1100 pp.

Planz, J.V. 1999. Northern rock mouse[,] Peromyscus nasutus. Pages 578-579 in D.E. Wilson and S. Ruff, editors, The Smithsonian book of North American mammals. Smithsonian Institution Press, Washington, DC. xxvi $+750 \mathrm{pp}$.

REID, F. 2006. A field guide to mammals of North America north of Mexico. 4th edition. Houghton Mifflin Company, Boston, MA. xx +579 pp.

SCHAFER, T.S. 1991. Mammals of the Abajo Mountains, an isolated mountain range in San Juan County, southeastern Utah. Occasional Papers, The Museum, Texas Tech University 137:1-15.

Sutter, J.V., M.E. Andersen, K.D. Bunnell, M.F. Canning, A.G. Clark, D.E. Dolsen, and F.P. Howe. 
2005. Utah comprehensive wildlife conservation strategy. Publication number 05-19, Utah Division of Wildlife Resources, Salt Lake City. UtAh Division of WildLife Resources. 1997. Utah sensitive species list. Utah Division of Wildlife Resources, Salt Lake City. 46 pp.
1998. Utah sensitive species list. Utah Division of Wildlife Resources, Salt Lake City. 48 pp.

Received 27 July 2007 Accepted 10 October 2007 